\title{
Evaluation of Preemergence Herbicides for Crop Safety and Weed Control in Safflower
}

\author{
Prashant Jha*, Vipan Kumar, Charlemagne A. Lim, Ramawatar Yadav \\ Southern Agricultural Research Center, Department of Research Centers, Montana State University, Bozeman, MT, USA \\ Email: *pjha@montana.edu
}

How to cite this paper: Jha, P., Kumar, V., Lim, C.A. and Yadav, R. (2017) Evaluation of Preemergence Herbicides for Crop Safety and Weed Control in Safflower. American Journal of Plant Sciences, 8, 2358-2366. https://doi.org/10.4236/ajps.2017.810158

Received: August 10, 2017

Accepted: September 2, 2017

Published: September 5, 2017

Copyright $\odot 2017$ by authors and Scientific Research Publishing Inc. This work is licensed under the Creative Commons Attribution International License (CC BY 4.0).

http://creativecommons.org/licenses/by/4.0/ (c) (†) Open Access

\begin{abstract}
Weed management in safflower (Carthamus tinctorious L.) is a major challenge for growers due to very limited herbicide options available, particularly for broadleaf weed control. Field experiments were conducted at the Montana State University Southern Agricultural Research Center (MSU-SARC) near Huntley, MT in 2015 and 2016 to evaluate preemergence (PRE) soil-residual herbicides for crop safety and season-long broadleaf weed control in safflower. Among all herbicide programs tested, only sulfentrazone (105 g.ai $\cdot \mathrm{ha}^{-1}$ ) alone or with pendimethalin (1064 g.ai $\cdot \mathrm{ha}^{-1}$ ) caused $4 \%$ to $12 \%$ early-season visible injury to safflower, although the injury was not evident beyond 30 DAT. Sulfentrazone alone or with pendimethalin and pyroxasulfone (59 g.ai.ha $\left.{ }^{-1}\right)$ with pendimethalin had a season-long residual activity on kochia [Kochia scoparia (L.) Schrad] and Russian-thistle (Salsola tragus L), with $89 \%$ to $99 \%$ control at $60 \mathrm{DAT}$, and up to $98 \%$ reduction in weed density compared with dimethenamid-P (213 g.ai.ha ${ }^{-1}$ ) and $S$-metolachlor (433 g.ai $\cdot \mathrm{ha}^{-1}$ ) at $65 \mathrm{DAT}$. Pyroxasulfone (59 or $118 \mathrm{~g} \cdot \mathrm{ai} \cdot \mathrm{ha}^{-1}$ ) alone or dimethenamid-P with pendimethalin provided a moderate to good control (65\% to $79 \%$ at $60 \mathrm{DAT})$ of kochia and Russian-thistle. However, the end-season control of kochia or Russian-thistle was inadequate $(<50 \%$ control) with pendimethalin, dimethenamid-P, or $S$-metolachlor alone program. Safflower grain yield with sulfentrazone alone or with pendimethalin, pyroxasulfone alone or with pendimethalin, and dimethenamid-P with pendimethalin averaged $3559 \mathrm{~kg} \cdot \mathrm{ha}^{-1}$, which was $195 \%$ higher compared with the nontreated check. In conclusion, sulfentrazone and pyroxasulfone or dimethenamid-P in combination with pendimethalin will be effective PRE herbicide programs for kochia and Russian-thistle control in safflower.
\end{abstract}

\section{Keywords}

Safflower, Weed Control, Preemergence Herbicide, Kochia, Russian-Thistle 


\section{Introduction}

Safflower is an annual oilseed crop well adapted to the semiarid regions of the US Great Plains and Canada. Safflower possesses a deep taproot system, which can extend to a depth of 2 to $3 \mathrm{~m}$ into the soil, and is more tolerant to drought stress compared to other oilseed and small grain crops [1] [2]. Therefore, safflower would be a potential fit as a second crop in the dryland winter wheat-fallow rotations in this region [3] [4]. In 2015, Montana ranked second among the safflower producing states, with $13 \%$ of the total US safflower production [5]. In the absence of weed interference, safflower grain yields can exceed $2000 \mathrm{~kg} \cdot \mathrm{ha}^{-1}$ when grown after winter wheat [2]. However, safflower is a poor competitor with weeds, and weed control is one of the major production challenges for successful adoption of this crop [4] [6]. Safflower seedlings remain in the rosette stage for 3 to 4 weeks after emergence and the canopy closure occurs late in the season; hence, early-emerging weeds species can easily outgrow and shade the crop [4]. A season-long weed interference in safflower can reduce grain yields by 93\% [4] [6].

Trifluralin, EPTC, ethalfluralin, and $S$-metolachlor are the preemergence (PRE)/ preplant incorporated (PPI) herbicides labeled for use in safflower [1] [7]. Trifluralin (applied PPI) was the first herbicide labeled for use in safflower [8]. It is effective on some annual grasses, but does not adequately control Brassica species, kochia, and Russian-thistle. These weed species are particularly troublesome in safflower production areas of this region, including Montana [1] [4] [6]. Furthermore, the need for soil-incorporation of trifluralin, ethalfluranlin, and EPTC for optimum weed control often limits their use in no-tillage semi-arid cropping systems of this region. $S$-metolachlor applied PRE controls annual grasses and few broadleaf weeds such as pigweeds (Amaranthus species) [9] [10]. During 1980s, sulfonylurea (SU) herbicides such as chlorsulfuron, metsulfuron, and thiameturon (now thifensulfuron) were tested, particularly for postemergence (POST) broadleaf weed control, in safflower [4] [6]. Previous studies found that safflower exhibits variable tolerance to these SU herbicides, and moderate to severe injury may occur if applied to safflower plants less than 15-cm tall [4] [11]. This is a major limitation in using these SU herbicides for early-season POST weed control, especially for weeds such as kochia and Russian-thistle, which can emerge very early in the spring before or with safflower seedlings in the US Great Plains [6] [12]. Thifensulfuron is the only POST herbicide currently labeled for broadleaf weed control in safflower in the US [1]. However, the widespread occurrence of ALS-resistant kochia and Russian-thistle in Montana and several other states in the US Great Plains [13] renders thifensulfuron ineffective for controlling these weed biotypes in safflower.

Therefore, there is a need to investigate alternative herbicide programs for improved broadleaf weed control in safflower, especially kochia and Russian-thistle, and to facilitate registration of new products for use in safflower. The objective of this research was to investigate effective PRE soil-residual her- 
bicide programs for improved crop safety and season-long broadleaf weed control in safflower.

\section{Materials and Methods}

\subsection{Experimental Setup}

Field experiments were conducted in 2015 and 2016 at the Montana State University Southern Agricultural Research Center (45.92" $\left.{ }^{\circ} 108.25^{\prime \prime W}\right)$ near Huntley, MT. Soil at the test site was Fort Collins clay loam, fine-loamy, mixed, superactive, mesic Aridic Haplustalfs, with a $\mathrm{pH}$ of $7.8 \%$ and $2.1 \%$ organic matter. Safflower was planted with a no-till drill intoa field that had been fallowed last year. A pre-plant burndown application of glyphosate (Roundup Powermax ${ }^{\circledast}$, Monsanto Company, Saint Louis, MO 63,167) at $1260 \mathrm{~g} \cdot \mathrm{ai} \cdot \mathrm{ha}^{-1}$ was applied in the spring to kill existing weeds prior to safflower planting. Plots were fertilized with Nitrogen-Phosphorous-Potash as per Montana State University and North Dakota State University recommendations for safflower production [1]. Safflower variety "MonDak" (Safflower Technologies International, PO Box 907, Laurel, MT 59,044) was planted on April 25, 2015 and May 2, 2016 in 30-cm rows at a depth of $2.5 \mathrm{~cm}$ with a seeding rate of $22 \mathrm{~kg} \cdot \mathrm{ha}^{-1}$ to obtain $20 \mathrm{plants} \cdot \mathrm{m}^{-1}$ of row. This variety has an average plant height of $56 \mathrm{~cm}$ and possesses a pure white seed (normal hull), with an average seed yield of $2158 \mathrm{~kg} \cdot \mathrm{ha}^{-1}$ and oil content (rich in oleic acid) of $35.4 \%$ [1]. Safflower seedlings emerged approximately one week after planting in both years. Experiments were conducted under dryland conditions. Monthly mean temperature and accumulated rainfall at the test site in 2015 and 2016 are shown in Table 1.

Treatments were arranged in a randomized complete block design with four replications, and plots were $3 \mathrm{~m}$ wide by $9 \mathrm{~m}$ long. Preemergence (PRE) herbicide treatments listed in Table 2 were applied on April 25, 2015 and May 2, 2016. A non treated check was included for comparison. All herbicide treatments were applied with a $\mathrm{CO}_{2}$-pressurized backpack sprayer calibrated to deliver $187 \mathrm{~L} \cdot \mathrm{ha}^{-1}$ at $186 \mathrm{kPa}$ using XR11002 flat-fan spray nozzles. Each year, the test site had a natural uniform infestation of kochia and Russian thistle.

Table 1. Monthly mean air temperature and total precipitation for 2015 and 2016 safflower growing seasons at the MSU Southern Agricultural Research Center near Huntley, MT.

\begin{tabular}{ccccc}
\hline \multicolumn{2}{c}{2015} & \multicolumn{2}{c}{2016} \\
\hline Mar & Temperature (C) & Precipitation (mm) & Temperature (C) & Precipitation (mm) \\
Apr & 6.8 & 3.6 & 5.4 & 43.7 \\
May & 12.9 & 29.0 & 9.7 & 45.3 \\
Jun & 20.8 & 79.1 & 13.4 & 75.0 \\
Jul & 22.2 & 50.9 & 21.0 & 99.1 \\
Aug & 21.0 & 26.4 & 22.7 & 12.0 \\
\hline
\end{tabular}


Table 2. List of tested preemergence (PRE) herbicides in safflower.

\begin{tabular}{ccc}
\hline Active ingredients & Trade name & Manufacturer \\
\hline Dimethenamid-P & Outlook $^{\oplus}$ & BASF Corporation, Research Triangle Park, NC 27709 \\
Pendimethalin & Prowl $^{\star} \mathrm{H}_{2} 0$ & BASF Corporation, Research Triangle Park, NC 27709 \\
Pyroxasulfone & Zidua $^{\star}$ & BASF Corporation, Research Triangle Park, NC 27709 \\
S-metolachlor & Dual II Magnum $^{\odot}$ & Syngenta Crop Protection, Greensboro, NC 27419 \\
Sulfentrazone & Spartan $^{\star} 4 \mathrm{~F}$ & FMC Corporation, Philadelphia, PA 91103
\end{tabular}

Percent crop injury and weed control were visually rated on a scale of 0 (no injury) to 100 (complete injury/plant death) at 7, 15, 30, and 60 days after treatment (DAT) of the PRE herbicide. The end-season (65 DAT) weed density was enumerated by species in a $1-\mathrm{m}^{2}$ quadrat placed at the center of each plot. Safflower and weed heights were recorded 10 weeks after treatment (WAT) by measuring the height from the soil surface to the highest growing point from ten randomly selected plants per plot. Days to flowering (100\% of plants with at least one fully open flower) were also recorded in order to further assess crop injury. At physiological maturity, safflower was harvested using a plot-combine on August 20, 2015 and August 28, 2016. Safflower grain samples were cleaned, and yields were adjusted to $13 \%$ moisture.

\subsection{Statistical Analysis}

All data were subjected to ANOVA using the MIXED procedure in SAS 9.3 (SAS Institute, Cary, NC). Data on crop injury and weed control were arcsine-transformed and weed density data were square-root-transformed before analysis to improve homogeneity of variances and normality of residuals. Non transformed means are presented in tables based on the interpretations from the transformed data. Year, herbicide treatment, and their interactions were fixed effects, and replication and interactions involving this variable were random effects in the model. Data were pooled across locations whenever year by herbicide treatment interaction was not significant. Means were separated using Fisher's protected LSD test at $\mathrm{P}<0.05$.

\section{Results and Discussion}

The 2016 growing season was slightly wetter compared to the 2015 growing season (Table 1). However, the treatment by year interaction was not significant on safflower visual injury, weed density, percent weed control, or safflower grain yield; therefore, data were pooled over years.

\subsection{Safflower Injury}

None of the PRE herbicide programs, except sulfentrazone alone or with pendimethalin injured safflower. Sulfentrazone at $105 \mathrm{~g} \cdot \mathrm{ai} \cdot \mathrm{ha}^{-1}$ alone and with pendimethalin (1064 g.ai ha ${ }^{-1}$ ) caused $9 \%$ and $12 \%$ injury, respectively, to safflower 15 
DAT. However, the injury was less than $5 \%$ with those herbicides at 30 DAT. Those plants fully recovered from the herbicide injury by 40 DAT (data not shown). Across treatments, safflower plants were 70 to $73 \mathrm{~cm}$ in height at 10 WAT in both years. Safflower in all plots flowered by 80 to 83 DAT in both years, further indicating no injury from any of the PRE herbicide treatments.

\subsection{Kochia Control}

Pyroxasulfone alone provided greater kochia control when applied PRE at 118 (high rate) compared to 59 (low rate) g.ai hat ${ }^{-1}$ at $30 \mathrm{DAT}$ (Table 3). However, addition of pendimethalin $\left(1064 \mathrm{~g} \cdot \mathrm{ai} \cdot \mathrm{ha}^{-1}\right)$ with the low rate of pyroxasulfone improved residual control of kochia from $85 \%$ to $96 \%$ at 30 DAT. Sulfentrazone $\left(105 \mathrm{~g} \cdot \mathrm{ai} \cdot \mathrm{ha}^{-1}\right)$ alone or with pendimethalin provided an excellent kochia control (98\% to $99 \%$ ) at 30 DAT. Kochia control 30 DAT with pendimethalin alone at $1064 \mathrm{~g} \cdot \mathrm{ai} \cdot \mathrm{ha}^{-1}$ was moderate $(66 \%)$, with a slight improvement in control $(75 \%)$ when tank mixed with dimethenamid-P at $213 \mathrm{~g} \cdot \mathrm{ai} \cdot \mathrm{ha}^{-1}$ (Table 3 ).

Kochia control 45 DAT with sulfentrazone alone or with pendimethalin, and pyroxasulfone (low rate) + pendimethalin ranged from $91 \%$ to $99 \%$. Addition of dimethenamid-P to pendimethalin also improved kochia control from $55 \%$ to $76 \%$ at $45 \mathrm{DAT}$. However, pyroxasulfone (low rate) + pendimethalin treatment did not differ from pyroxasulfone alone treatment applied at the high rate (Table 3 ).

Among all PRE herbicide treatments, there was a greater decline in kochia control with pyroxasulfone alone (low or high rate) or pendimethalin alone

Table 3. Effect of preemergence herbicide treatments on crop injury, kochia and Russian-thistle density and control in safflower near Huntley, MT, averaged over 2015 and $2016^{\mathrm{a}}$.

\begin{tabular}{|c|c|c|c|c|c|c|c|c|c|c|c|c|c|c|c|c|c|c|c|c|c|}
\hline \multirow[b]{3}{*}{ Treatment } & \multirow[b]{3}{*}{ Rate } & & & & \multicolumn{9}{|c|}{ Kochia } & \multicolumn{8}{|c|}{ Russian-thistle } \\
\hline & & \multicolumn{3}{|c|}{ Crop injury } & \multicolumn{3}{|c|}{ Density } & \multicolumn{4}{|c|}{ Control } & \multicolumn{4}{|c|}{ Density } & \multicolumn{6}{|c|}{ Control } \\
\hline & & \multicolumn{2}{|c|}{15 DAT } & \multicolumn{2}{|c|}{$30 \mathrm{DAT}$} & \multicolumn{2}{|c|}{$65 \mathrm{DAT}$} & \multicolumn{2}{|c|}{$30 \mathrm{DAT}$} & \multicolumn{2}{|c|}{45 DAT } & \multicolumn{2}{|c|}{$60 \mathrm{DAT}$} & \multicolumn{2}{|c|}{65 DAT } & \multicolumn{2}{|c|}{$30 \mathrm{DAT}$} & \multicolumn{2}{|c|}{$45 \mathrm{DAT}$} & \multicolumn{2}{|c|}{$60 \mathrm{DAT}$} \\
\hline & $\left(\mathrm{g} \cdot \mathrm{ai} \cdot \mathrm{ha}^{-1}\right)$ & \multicolumn{4}{|c|}{$\%$} & \multicolumn{2}{|c|}{$\mathrm{m}^{-2}$} & \multicolumn{6}{|c|}{$\%$} & \multicolumn{2}{|c|}{$\mathrm{m}^{-2}$} & \multicolumn{6}{|c|}{$\%$} \\
\hline Dimethenamid-P & 213 & 0 & & 0 & & 52 & $\mathrm{a}$ & 14 & $\mathrm{e}$ & 9 & $\mathrm{f}$ & 5 & $\mathrm{~d}$ & 12 & $\mathrm{a}$ & 72 & $\mathrm{~d}$ & 56 & $\mathrm{e}$ & 47 & c \\
\hline Pyroxasulfone & 59 & 0 & & 0 & & 20 & c & 85 & $\mathrm{~b}$ & 75 & $\mathrm{~d}$ & 65 & $\mathrm{~b}$ & 4 & $\mathrm{~b}$ & 86 & c & 80 & $\mathrm{bc}$ & 74 & $\mathrm{~b}$ \\
\hline Pyroxasulfone & 118 & 0 & & 0 & & 14 & $\mathrm{~cd}$ & 94 & $\mathrm{a}$ & 84 & $\mathrm{bc}$ & 74 & $\mathrm{~b}$ & 2 & $\mathrm{~b}$ & 91 & $\mathrm{bc}$ & 85 & $\mathrm{~b}$ & 79 & $\mathrm{~b}$ \\
\hline$S$-Metolachlor & 433 & 0 & & 0 & & 48 & $\mathrm{a}$ & 15 & $\mathrm{e}$ & 15 & $\mathrm{f}$ & 14 & $\mathrm{~d}$ & 14 & $\mathrm{a}$ & 47 & e & 37 & $\mathrm{f}$ & 31 & $\mathrm{~d}$ \\
\hline $\begin{array}{l}\text { Dimethenamid-P } \\
+ \text { pendimethalin }\end{array}$ & $1064+213$ & 0 & & 0 & & 12 & $\mathrm{de}$ & 75 & c & 76 & $\mathrm{~cd}$ & 74 & $\mathrm{~b}$ & 4 & $\mathrm{~b}$ & 76 & $\mathrm{~d}$ & 75 & c & 75 & $\mathrm{~b}$ \\
\hline $\begin{array}{l}\text { Pyroxasulfone }+ \\
\text { pendimethalin }\end{array}$ & $59+1064$ & 0 & & 0 & & 6 & ef & 96 & $\mathrm{a}$ & 91 & $\mathrm{ab}$ & 89 & $\mathrm{a}$ & 1 & $\mathrm{~b}$ & 95 & $\mathrm{ab}$ & 94 & $\mathrm{a}$ & 92 & $\mathrm{a}$ \\
\hline Sulfentrazone & 105 & 9 & $\mathrm{~b}$ & 4 & $\mathrm{a}$ & 1 & $\mathrm{f}$ & 98 & $\mathrm{a}$ & 99 & $\mathrm{a}$ & 99 & $\mathrm{a}$ & 1 & $\mathrm{~b}$ & 98 & $\mathrm{a}$ & 99 & $\mathrm{a}$ & 99 & a \\
\hline $\begin{array}{l}\text { Sulfentrazone }+ \\
\text { pendimethalin }\end{array}$ & $105+1064$ & 12 & $\mathrm{a}$ & 4 & $\mathrm{a}$ & 1 & $\mathrm{f}$ & 99 & $\mathrm{a}$ & 99 & $\mathrm{a}$ & 99 & $\mathrm{a}$ & 1 & $\mathrm{~b}$ & 97 & $\mathrm{a}$ & 98 & $\mathrm{a}$ & 99 & a \\
\hline
\end{tabular}

${ }^{\mathrm{a}}$ Means within a column followed by similar letters are not significantly different based on Fisher's protected LSD at P $<0.05$. 
treatment when compared at 60 vs. $30 \mathrm{DAT}$. For instance, control with pendimethalin alone declined from $66 \%$ at $30 \mathrm{DAT}$ to $35 \%$ at $60 \mathrm{DAT}$. The results indicate that these herbicides when applied alone may not provide season-long kochia control in safflower. Similarly, in a previous research conducted in corn, kochia control with pyroxasulfone PRE applied even at a higher rate of 149 or 298 g.ai.ha ${ }^{-1}$ declined from $76 \%$ at $21 \mathrm{DAT}$ to $53 \%$ at $63 \mathrm{DAT}$ [14]. A decline in the residual activity of pyroxasulfone beyond $28 \mathrm{DAT}$ has also been reported in other broadleaf weeds such as velvetleaf (Abutilon theophrasti Medik.) and tall waterhemp [Amaranthustuberculatus (Moq.) Sauer] [15]. In our study, pyroxasulfone + pendimethalin, sulfentrazone alone, and sulfentrazone + pendimethalin provided an excellent season-long residual control of kochia, which was $89 \%$ to $99 \%$ at $60 \mathrm{DAT}$. Also in a previous research, the addition of pendimethalin at a similar rate enhanced the residual activity of pyroxasulfone (119 g.ai.ha $\left.{ }^{-1}\right)$ on kochia and other weed species including common lambsquarters (Chenopodium album L.) and wild buckwheat (Polygonum convolvulus L.) at 21, 35, and 63 DAT [14]. Dimethenamid-P alone and $S$-metolachlor alone were the least effective treatments for kochia control in safflower across all evaluation dates $(<20 \%$ control). Similarly, in a study conducted in corn, the end-season kochia control with dimethenamid-P or acetochlor (another chloroacetamide herbicide) did not exceed $32 \%$; however, the addition of pendimethalin to acetochlor significantly improved kochia control [14].

A poor control from dimethenamid-P and $S$-metolachlor resulted in an average of 50 kochia plants $\mathrm{m}^{-2}$ by the end of the season (65 DAT) (Table 3). Kochia plants in those treatments grew above the safflower crop canopy, with an average plant height of $130 \mathrm{~cm}$ at 10 WAT (data not shown). Furthermore, those kochia plants were green at the time of safflower harvest. Kochia density in the pyroxasulfone alone treatments averaged 17 plants $\mathrm{m}^{-2}$, with an average height of 80 $\mathrm{cm}$ at $10 \mathrm{WAT}$. The end-season kochia density did not exceed 6 plants $\cdot \mathrm{m}^{-2}$ because of the extended residual activity from sulfentrazone alone, sulfentrazone + pendimethalin, and pyroxasulfone + pendimethalin treatments. In addition, kochia plants in those plots were much below the safflower canopy, with an average height not exceeding $18 \mathrm{~cm}$ at $10 \mathrm{WAT}$ (data not shown).

\subsection{Russian-Thistle Control}

Sulfentrazone, sulfentrazone + pendimethalin, and pyroxasulfone + pendimethalin controlled Russian-thistle by $95 \%$ to $98 \%$ at 30 DAT. Control with pyroxasulfone at the high and low rates did not differ, and averaged $88 \%$ at 30 DAT. Control 30 DAT with pendimethalin or dimethenamid-P alone was consistent with pendimethalin + dimethenamid-P, and ranged from $72 \%$ to $76 \%$.

At 45 DAT, Russian-thistle control with pendimethalin + dimethenamid-P (75\%) was better than pendimethalin alone $(65 \%)$ or dimethenamid-P alone (56\%), indicating an enhancement of residual activity on Russian-thistle when the two herbicides were applied in combination. Pyroxasulfone alone at the high and low rates provided $82 \%$ average control of Russian-thistle in safflower 45 
DAT. Similar to kochia control, the addition of pendimethalin to pyroxasulfone (low rate) improved the residual activity on Russian-thistle ( $94 \%$ control) compared with pyroxasulfone alone (low or high rate) (Table 3 ).

At 60 DAT, Russian-thistle control with pendimethalin alone or dimethenamid-P alone further declined, and was inadequate $(<50 \%)$. Control with pyroxasulfone + pendimethalin $(92 \%)$ was superior to pendimethalin + dimethenamid-P (75\%) at $60 \mathrm{DAT}$. Consistent with pyroxasulfone + pendimethalin, sulfentrazone alone or with pendimethalin provided $99 \%$ control 60 DAT. $S$-metolachlor was the least effective treatment ( $<50 \%$ control) across all evaluation dates.

Consistent with control estimates, the end-season (65 DAT) Russian-thistle density was 11 to 14 plants. $\mathrm{m}^{-2}$ with the less effective treatments, viz., pendimethalin, dimethenamid-P, and $S$-metolachlor alone. Although Russian-thistle plants in those plots were below the safflower crop canopy, they were 54 to $53 \mathrm{~cm}$ in height at 10 WAT (data not shown). Russian-thistle density in the remaining treatments was reduced to $1-4$ plants $\mathrm{m}^{-2}$, with a plant height not exceeding 12 $\mathrm{cm}$ at $10 \mathrm{WAT}$.

\subsection{Safflower Grain Yield}

Consistent with the weed control, safflower yield was higher in pyroxasulfone alone (low or high rate), pyroxasulfone + pendimethalin, dimethenamid-P + pendimethalin, sulfentrazone alone, and sulfentrazone + pendimethalin compared with the remaining herbicide treatments, and ranged from 3388 to $3690 \mathrm{~kg} \cdot \mathrm{ha}^{-1}$ (Table 4). In contrast, grain yield with pendimethalin, dimethenamid-P, and $S$-metolachlor alone treatments averaged $2080 \mathrm{~kg} \cdot \mathrm{ha}^{-1}$. A season-long interference of kochia and Russian-thistle reduced the safflower grain yield by $66 \%$ in the nontreated check plots, compared with the top six high yielding treatments.

Table 4. Effect of preemergence herbicide treatments on safflower grain yield at Huntley, MT, averaged over 2015 and $2016^{\mathrm{a}}$.

\begin{tabular}{cccc}
\hline Treatment & Rate & Yield \\
\hline Pendimethalin & g.ai $\cdot \mathrm{ha}^{-1}$ & $\mathrm{~kg} \cdot \mathrm{ha}^{-1}$ & $\mathrm{~b}$ \\
Dimethenamid-P & 1064 & 2249 & $\mathrm{~b}$ \\
Pyroxasulfone & 213 & 2163 & $\mathrm{a}$ \\
Pyroxasulfone & 59 & 3388 & $\mathrm{a}$ \\
S-Metolachlor & 118 & 3447 & $\mathrm{bc}$ \\
Dimethenamid-P + pendimethalin & 433 & 3511 & $\mathrm{a}$ \\
Pyroxasulfone + pendimethalin & $1064+213$ & 3635 & $\mathrm{a}$ \\
Sulfentrazone & $59+1064$ & 3686 & $\mathrm{a}$ \\
Sulfentrazone + pendimethalin & $105+1064$ & 3690 & $\mathrm{a}$ \\
Nontreated check & - & 1205 & $\mathrm{c}$ \\
\hline
\end{tabular}

${ }^{a}$ Means within a column followed by similar letters are not significantly different based on Fisher's protected LSD at $\mathrm{P}<0.05$. 


\section{Conclusion}

This is the first published information on the efficacy of these PRE herbicides for crop safety and broadleaf weed control in safflower. Only sulfentrazone (105 $\mathrm{g} \cdot \mathrm{a} \cdot \mathrm{ha} \mathrm{h}^{-1}$ ) alone or with pendimethalin (1064 g.ai.ha ${ }^{-1}$ ) applied PRE caused some early-season visual injury ( $4 \%$ to $12 \%$ ) to safflower, although it did not influence safflower plant height, flowering time, or grain yield. Results indicated that sulfentrazone alone or with pendimethalin and pyroxasulfone (59 g.ai.ha $\left.{ }^{-1}\right)+$ pendimethalin can effectively control (up to $99 \%$ ) and prevent yield reductions from kochia and Russian-thistle interference in safflower. Pyroxasulfone alone at 59 or $118 \mathrm{~g} \cdot \mathrm{ai} \cdot \mathrm{ha}^{-1}$ was moderately effective in controlling kochia and Russian-thistle (65\% to $79 \%$ end-season control) and prevented yield reductions; whereas, pendimethalin, dimethenamid-P, and metolachlor alone were ineffective in controlling those weeds in safflower. This research may facilitate registration of pyroxasulfone, dimethenamid-P, pendimethalin, or sulfentrazone for broadleaf weed control in safflower at the use rates evaluated, which will potentially allow growers to successfully adopt safflower in dryland wheat-based crop rotations in this region.

\section{Acknowledgements}

We thank Mr. Shane Leland for his technical assistance in conducting the research. We also thank BASF and FMC Corporation for funding this research.

\section{References}

[1] Bergman, J. and Kandel, H. (2013) Safflower Production-A870. NDSU Extension Service, Fargo.

https://www.ag.ndsu.edu/publications/landing-pages/crops/safflower-production-a$\underline{870}$

[2] Martin, J.H., Leonard, W.H. and Stamp, D.L. (1976) Safflowers. Pages 1977-1980 in Principles of Field Crop Production. MacMillan Publishing Co., Inc., New York.

[3] Anderson, R.L. (1985) Chlorsulfuron for Weed Control in Safflower (Carthamustinctorius). Weed Science, 33, 840-842.

[4] Anderson, R.L. (1987) Broadleaf Weed Control in Safflower (Carthamustinctorius) with Sulfonylurea Herbicides. Weed Technology, 1, 242-246.

[5] USDA-NASS (United States Department of Agriculture National Agricultural Statistics Service) (2017) Montana Agricultural Facts 2016. USDA-NASS, Helena. https://www.nass.usda.gov/Statistics_by_State/Montana/Publications/Special_Intere st_Reports/agfacts.pdf

[6] Blackshaw, R.E., Muendel, R.H. and Derksen, D.A. (1990) Herbicides for Weed Control in Safflower (Carthamustinctorius). Canadian Journal of Plant Science, 70, 237-245. https://doi.org/10.4141/cjps90-026

[7] Zollinger, R., Christoffers, M., Endres, G., Dalley, C., Endres, G., Gramig, G., Howatt, K., Jenks, B., Keene, C., Lym, R., Ostlie, M., Peters, T., Robinson, A., Thostenson, A. and Valenti, H.H. (2017) North Dakota Weed Control Guide. W-253. NDSU Extension Service, Fargo.

https://www.ag.ndsu.edu/weeds/weed-control-guides/nd-weed-control-guide-1 
[8] Helm, J.L., Riveland, N., Schneiter, A.A. and Sobolik, F. (1985) Safflower Production. Crop Extension Service, North Dakota State University, Fargo.

[9] Anonymous (2005) Outlook Herbicide Product Label. BASF Corporation, Research Triangle Park, NC, 18.

[10] Bollman, S.L. and Sprague, C.L. (2007) Optimizing S-Metolachlor and Dimethenamid-P in Sugar Beet Microrate Treatments. Weed Technology, 21, 1054-1063. https://doi.org/10.1614/WT-07-068.1

[11] Friesen, G.H. (1986) Broadleaved Weed Control in Safflower. Research Report, Expert Committee on Weeds, Western Canada Section Meeting, 358.

[12] Blackshaw, R.E., Morrison, R.J., Muendel, R.H. and Roth, B.T. (1992) Weed Control in Safflower (Carthamustinctorius) by Flurtamone. Weed Science, 40, 110-114.

[13] Heap, I.M. (2017) The International Survey of Herbicide Resistant Weeds. http://www.weedscience.org

[14] Jha, P., Kumar, V., Garcia, J. and Reichard, N. (2015) Tank Mixing Pendimethalin with Pyroxasulfone and Chloroacetamide Herbicides Enhances In-Season Residual Weed Control in Corn. Weed Technology, 29, 198-206. https://doi.org/10.1614/WT-D-14-00095.1

[15] Knezevic, S.Z., Datta, A., Scott, J. and Porpiglia, P.J. (2009) Dose-Response Curves of KIH485 for Preemergence Weed Control in Corn. Weed Technology, 23, 34-39. https://doi.org/10.1614/WT-08-097.1

\section{Submit or recommend next manuscript to SCIRP and we will provide best} service for you:

Accepting pre-submission inquiries through Email, Facebook, LinkedIn, Twitter, etc. A wide selection of journals (inclusive of 9 subjects, more than 200 journals)

Providing 24-hour high-quality service

User-friendly online submission system

Fair and swift peer-review system

Efficient typesetting and proofreading procedure

Display of the result of downloads and visits, as well as the number of cited articles

Maximum dissemination of your research work

Submit your manuscript at: http://papersubmission.scirp.org/

Or contact ajps@scirp.org 